\title{
The solvent and substituent effects on bond dissociation energies of NO-donor molecules containing the N-NO bond
}

\author{
LI XIAO-HONG ${ }^{\mathrm{a}, *}$, LI WEI-BIN ${ }^{\mathrm{b}}$ and ZHANG XIAN-ZHOU \\ ${ }^{a}$ College of Physics and Engineering, Henan University of Science and Technology, \\ Luoyang 471003 China \\ ${ }^{b}$ Department of Physics and Chemistry, Henan polytechnic University, Jiaozuo 454000 China \\ ${ }^{c}$ College of Physics and Information Engineering, Henan Normal University, Xinxiang 453007 China \\ e-mail: lorna639@126.com
}

MS received 16 July 2009; revised 27 January 2010; accepted 1 June 2010

\begin{abstract}
Quantum chemical calculations are used to estimate the equilibrium N-NO bond dissociation energies (BDEs) for 15 NO-donor molecules in acetonitrile. These compounds are studied by employing the hybrid density functional theory (B3LYP, B3PW91, B3P86) methods together with 6-31G** basis set. The basis set superposition error (BSSE) and zero-point vibrational energy (ZPVE) are considered. The results are compared with the available experimental results. It is demonstrated that B3LYP/6-31G** is accurate to compute the reliable BDEs for the NO-donor molecules. The solvent effects on the N-NO BDEs are analysed and the result shows that the N-NO BDEs in a vacuum computed by B3P86/6-31G** method are the closest to the computed values in acetontrile and the average solvent effect is $0.78 \mathrm{kcal} /$ mol. Subsequently, the substituent effects on the N-NO BDEs are further analysed and it is found that electron donating group stabilizes the radical and as a result BDE decreases; whereas electron withdrawing group stabilizes the ground state of the molecule and thus increases the BDE.
\end{abstract}

Keywords. Bond dissociation energy; density functional theory; NO-donor molecule; geometry optimization.

\section{Introduction}

Nitric oxide (NO) is a simple intra- and intercellular signalling molecule playing important roles in many physiological processes. ${ }^{1}$ Its biological functions include regulating the blood pressure, transmitting neurostimulation, and participating in the immune systems to kill tumor cells and intracellular parasites. As a free radical, NO is highly reactive in the biological environment. Therefore, to use NO efficiently and safely, the biological systems have to evolve certain NO-carrying vehicles for NO storage, transport, and delivery.

As a unique class of such NO-carrying vehicles, $\mathrm{N}$-nitroso compounds are believed to take a most active part in many biological functions of nitric oxide, especially in the process of NO-storage, transport, and delivery. ${ }^{2-4}$ In addition, many $\mathrm{N}$-nitroso compounds in which a double bond is attached to the NO-bearing nitrogen showed anti-

\footnotetext{
*For correspondence
}

cancer activity. ${ }^{5}$ The use of $N$-nitroso compounds as NO donors in many chemical and biological reaction systems has also long been recongnized. ${ }^{6}$ Therefore it is believed that quantitative measures of the $\mathrm{N}-\mathrm{NO}$ bond energies may serve as a guide for selecting efficient NO donor compounds and for a more insightful understanding of relevant NOinvolving reactions. For most small and medium size compounds experimental BDEs are always determined directly. But for large molecules, especially those unstable molecules, it is very difficult to experimentally determine the stability of these molecules. For this purpose, it would be important to find a reliable theoretical calculations and predictions of the BDEs for the studied molecules. Four series of $\mathrm{N}$-nitroso compounds are listed in figure 1 .

Due to the rapid progress in computational methods, highly sophisticated calculations can be performed, with minor errors in comparison to experimental data. Gaussian family of methods $(\mathrm{G} 1, \mathrm{G} 2$, G2MP2, G3) and the complete basis set extrapolation (CBS) approach have been used to predict reac- 
tion enthalpies and thermochemical properties (enthalpies of formation, for instance) ${ }^{7-11}$ But these methods cited above are computationally very expensive. An alternative to these high cost calculations is the use of density functional (DFT) methods.

Different calculational methods are generally applied to compute the BDE for various kinds of molecular systems. Recently, Zhao and Truhlar ${ }^{12}$ group developed some density functionals. These density functionals depend on the spin and the reduced gradient or spin kinetic energy densities or are a combination of generalized gradient approximation (GGA) with Hartree-Fock exchange. Tang et $a l^{13}$ have used some of the density functionals developed by Truhlar group to compute the bond dissociation energy (BDE) of terminal $\mathrm{N}-\mathrm{O}$ bond for several pyridine $\mathrm{N}$-oxides compounds and compared the results with those computed by B3LYP, B3PW91 and B3P86 methods, respectively. The results show that B3PW91 is the most accurate method to compute the reliable BDE. In addition, we found that B3PW91/6-31G** method could produce satisfactory BDEs for S-nitrosothiols in acetonitrile $^{14}$ and B3P86/6-31G** method could produce satisfactory BDEs for $O$-nitrosyl carboxylate compounds in acetonitrile. ${ }^{15}$ For the N-NO bond in studied compounds, the report on the BDE is very few. If we can find out an accurate calculational method to compute BDEs of the N-NO bond, it would be possible to use this method to predict those molecules whose experimental BDEs are not available.

In the present work, our objective is to perform a systematic comparison of the BDEs for the N-NO bond dissociation of 15 compounds in acetonitrile solution. All the BDEs are calculated by employing

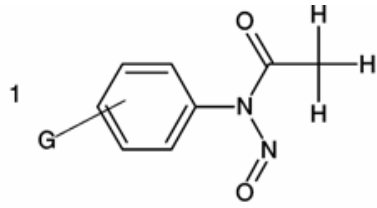

$\mathrm{G}=\mathrm{H}, 4-\mathrm{NO}_{2}, 4-\mathrm{Cl}$

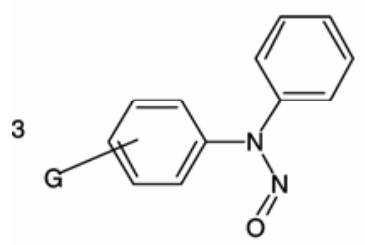

$\mathrm{G}=\mathrm{H}, 4-\mathrm{CH}_{3}, 3-\mathrm{Cl}$

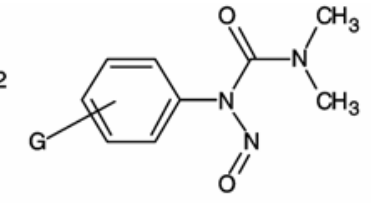

$\mathrm{G}=\mathrm{H}, 4-\mathrm{OCH}_{3}, 4-\mathrm{NO}_{2}, 4-\mathrm{Cl}$

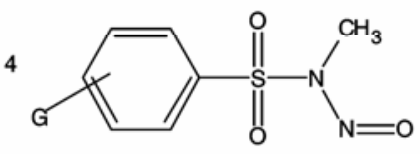

$\mathrm{G}=\mathrm{H}, 4-\mathrm{CH}_{3}, 4-\mathrm{CH}_{3} \mathrm{O}, 3-\mathrm{NO}_{2}, 4-\mathrm{Cl}$
Figure 1. Four series $N$-nitroso compounds. the hybrid density functional methods (B3LYP, B3PW91, B3P86). By comparing the calculated results with the available experimental values, the suitable method to compute BDEs of the N-NO bond is obtained. Further, we computed the N-NO bond dissociation energies of the 15 compounds in vacuum and compared the results with those in acetonitrile. Finally, substituent effect on BDE was analysed.

\section{Methods and computational details}

All calculations were performed with the Gaussian03 computational package. ${ }^{16}$ Geometry optimizations and subsequent normal mode analyses at the corresponding equilibrium structures were performed in $\mathrm{MeCN}$ solution for the products of the different bond scission reactions in which a single NO group is removed from the parent structure. The equilibrium geometries and bond dissociation energies were obtained at the Becke-style threeparameter density function theory ${ }^{17}$ with the LeeYang-Parr correlation function(LYP), ${ }^{18,19}$ the Perdew-Wang's 91 expression (PW91) ${ }^{20}$ and Perdew 1986 gradient corrected correlation functional. ${ }^{21}$ All calculations were performed at the $6-31 \mathrm{G}^{* *}$ basis set. The normal mode analysis for each structure resulted in no imaginary frequencies for the remaining $3 \mathrm{~N}-6$ vibrational degrees of freedom, where $\mathrm{N}$ is the number of atoms in the system. This indicates that the structure of each molecule corresponds to a local minimum on the potential energy surface.

Generally, computed BDEs are reported for gas phase conditions and it is expected that these values suffer variation in different environments such as those in living organism. So, it would be interesting to know what happens to these dissociation energies in the presence of solvent such as acetonitrile. The basis set superposition error (BSSE) and zero-point vibrational energy (ZPVE) are also considered in vacuum and acetonitrile, respectively.

The solvent effects of acetonitrile on the free energy change of N-NO homolysis were studied by using a continuum description of the solvent at B3LYP, B3PW91, B3P86 methods at the $6-31 \mathrm{G}^{* *}$ basis set. The polarized continuum model (PCM) developed by Tomasi ${ }^{22}$ was employed.

The N-NO bond strength is obtained by calculating the homolytic bond dissociation energy, which is defined here as the enthalpy change of the dissociation reaction: 


$$
R-X \rightarrow R^{*}+X^{*} .
$$

The bond dissociation energy of the $R-X$ bond is computed from the heats of formation at $298.15 \mathrm{~K}$ of the species involved in the dissociation, i.e.:

$$
E_{\mathrm{BDE}}=\Delta_{f} H_{298 \cdot 15, R}^{0}+\Delta_{f} H_{298 \cdot 15, X}^{0}-\Delta_{f} H_{298 \cdot 15, R X}^{0}
$$

For $N$-nitroso compounds studied here, the BDE is defined as the difference between the zero-pointcorrected energy of the parent molecule and that of the products of the unimolecular dissociation in which an NO group is removed. For example, for $\mathrm{C}_{6} \mathrm{H}_{5} \mathrm{SO}_{2} \mathrm{~N}\left(\mathrm{CH}_{3}\right)-\mathrm{NO}$, the BDE is

$$
\begin{aligned}
& B D E_{N-N O}=E\left(\mathrm{C}_{6} \mathrm{H}_{5} \mathrm{SO}_{2} \mathrm{~N}\left(\mathrm{CH}_{3}\right)\right)+ \\
& E(\mathrm{NO})-E\left(\mathrm{C}_{6} \mathrm{H}_{5} \mathrm{SO}_{2} \mathrm{~N}\left(\mathrm{CH}_{3}\right)-\mathrm{NO}\right) .
\end{aligned}
$$

The average errors of the BDEs for B3LYP, B3PW91, B3P86 methods are determined by calculating the average absolute error $\left(\varepsilon_{a a e}\right)$, defined as

$$
\varepsilon_{\mathrm{aae}}=\frac{1}{N} \sum_{i=1}^{N}\left|x_{i}-c_{i}\right|
$$

where $x_{i}$ represents the experimental data, $c_{i}$ denotes the calculated values and $N$ is the number of experimental or calculated data.

\section{Results and discussion}

\subsection{The BDEs of the N-NO bond in acetonitrile}

The BDE results computed by using B3LYP, B3P86 and B3PW91 three-parameter hybrid DFT methods with $6-31 \mathrm{G}^{* *}$ basis set are presented in table 1 . The available experimental values ${ }^{23,24}$ are also included in table 1. The BDEs of 15 compounds containing the $\mathrm{N}-\mathrm{NO}$ bond are compared with the corresponding experimental results for the system. It is noted that the BDEs calculated by B3PW91 method for 8 molecules are very poor and all the results calculated by B3PW91 method overestimate the BDEs for the compounds studied except 3-Cl- $\mathrm{C}_{6} \mathrm{H}_{4} \mathrm{~N}\left(\mathrm{C}_{6} \mathrm{H}_{5}\right)-$ $\mathrm{NO}, \quad 4-\mathrm{CH}_{3} \mathrm{O}-\mathrm{C}_{6} \mathrm{H}_{4} \mathrm{~N}\left(\mathrm{CON}\left(\mathrm{CH}_{3}\right)_{2}\right)-\mathrm{NO}, \quad \mathrm{C}_{6} \mathrm{H}_{5} \mathrm{~N}$ $\left(\mathrm{CON}\left(\mathrm{CH}_{3}\right)_{2}\right)-\mathrm{NO}, \quad 4-\mathrm{NO}_{2}-\mathrm{C}_{6} \mathrm{H}_{4} \mathrm{~N}\left(\mathrm{CON}\left(\mathrm{CH}_{3}\right)_{2}\right)-$ $\mathrm{NO}, 4-\mathrm{NO}_{2}-\mathrm{C}_{6} \mathrm{H}_{4} \mathrm{~N}\left(\mathrm{COCH}_{3}\right)-\mathrm{NO}$. The N-NO BDEs for the studied molecules have a considerable difference when compared with the experimental values. And B3PW91/6-31G** method has average absolute

\begin{tabular}{|c|c|c|c|c|c|}
\hline & & B3LYP & B3P86 & B3PW91 & $\operatorname{Exp}^{\mathrm{c}}$ \\
\hline Entry & Compound $^{\mathrm{b}}$ & $\mathrm{BDE}^{\mathrm{a}}$ & $\mathrm{BDE}^{\mathrm{a}}$ & $\mathrm{BDE}^{\mathrm{a}}$ & $\mathrm{BDE}$ \\
\hline 1 & $4-\mathrm{CH}_{3}-\mathrm{C}_{6} \mathrm{H}_{4} \mathrm{~N}\left(\mathrm{C}_{6} \mathrm{H}_{5}\right)-\mathrm{NO}$ & $28 \cdot 1(6 \cdot 7)$ & $33 \cdot 0(11 \cdot 6)$ & $30 \cdot 0(8 \cdot 9)$ & $21 \cdot 4$ \\
\hline 2 & $\mathrm{C}_{6} \mathrm{H}_{5} \mathrm{~N}\left(\mathrm{C}_{6} \mathrm{H}_{5}\right)-\mathrm{NO}$ & $32 \cdot 1(9 \cdot 5)$ & $35 \cdot 5(12 \cdot 9)$ & $34 \cdot 6(12 \cdot 0)$ & $22 \cdot 6$ \\
\hline 3 & $3-\mathrm{Cl}-\mathrm{C}_{6} \mathrm{H}_{4} \mathrm{~N}\left(\mathrm{C}_{6} \mathrm{H}_{5}\right)-\mathbf{N O}$ & $23 \cdot 0(-1 \cdot 1)$ & $28 \cdot 2(4 \cdot 1)$ & $24 \cdot 0(-0 \cdot 1)$ & $24 \cdot 1$ \\
\hline 4 & $3-\mathrm{NO}_{2}-\mathrm{C}_{6} \mathrm{H}_{4} \mathrm{SO}_{2} \mathrm{~N}\left(\mathrm{CH}_{3}\right)-\mathbf{N O}$ & $37 \cdot 8(3 \cdot 9)$ & $43 \cdot 1(9 \cdot 2)$ & $39 \cdot 9(6 \cdot 0)$ & 33.9 \\
\hline 5 & $4-\mathrm{CH}_{3}-\mathrm{C}_{6} \mathrm{H}_{4} \mathrm{SO}_{2} \mathrm{~N}\left(\mathrm{CH}_{3}\right)-\mathrm{NO}$ & $38 \cdot 9(5 \cdot 5)$ & $42 \cdot 5(9 \cdot 1)$ & $40 \cdot 9(7 \cdot 5)$ & $33 \cdot 4$ \\
\hline 6 & $\mathrm{C}_{6} \mathrm{H}_{5} \mathrm{SO}_{2} \mathrm{~N}\left(\mathrm{CH}_{3}\right)-\mathbf{N O}$ & $38 \cdot 8(3 \cdot 9)$ & $44 \cdot 0(9 \cdot 1)$ & $41 \cdot 0(6 \cdot 1)$ & $34 \cdot 9$ \\
\hline 7 & $4-\mathrm{Cl}-\mathrm{C}_{6} \mathrm{H}_{4} \mathrm{SO}_{2} \mathrm{~N}\left(\mathrm{CH}_{3}\right)-\mathrm{NO}$ & $38 \cdot 4(5 \cdot 4)$ & $44 \cdot 0(11 \cdot 0)$ & $40 \cdot 5(7 \cdot 5)$ & $33 \cdot 0$ \\
\hline 8 & $4-\mathrm{CH}_{3} \mathrm{O}-\mathrm{C}_{6} \mathrm{H}_{4} \mathrm{SO}_{2} \mathrm{~N}\left(\mathrm{CH}_{3}\right)-\mathrm{NO}$ & $38 \cdot 9(5 \cdot 2)$ & $42 \cdot 6(8 \cdot 9)$ & $41 \cdot 1(7 \cdot 6)$ & $33 \cdot 7$ \\
\hline 9 & $4-\mathrm{CH}_{3} \mathrm{O}-\mathrm{C}_{6} \mathrm{H}_{4} \mathrm{~N}\left(\mathrm{CON}\left(\mathrm{CH}_{3}\right)_{2}\right)-\mathbf{N O}$ & $23 \cdot 7(-4 \cdot 6)$ & $28 \cdot 4(0 \cdot 1)$ & $27 \cdot 5(-0 \cdot 8)$ & $28 \cdot 3$ \\
\hline 10 & $4-\mathrm{Cl}-\mathrm{C}_{6} \mathrm{H}_{4} \mathrm{~N}\left(\mathrm{CON}\left(\mathrm{CH}_{3}\right)_{2}\right)-\mathrm{NO}$ & $24 \cdot 7(-4 \cdot 5)$ & $29 \cdot 7(0 \cdot 5)$ & $29.9(0.7)$ & $29 \cdot 2$ \\
\hline 11 & $\mathrm{C}_{6} \mathrm{H}_{5} \mathrm{~N}\left(\mathrm{CON}\left(\mathrm{CH}_{3}\right)_{2}\right)-\mathrm{NO}$ & $24 \cdot 3(-4 \cdot 8)$ & $29 \cdot 2(0 \cdot 1)$ & $26 \cdot 4(-2 \cdot 7)$ & $29 \cdot 1$ \\
\hline 12 & $4-\mathrm{NO}_{2}-\mathrm{C}_{6} \mathrm{H}_{4} \mathrm{~N}\left(\mathrm{CON}\left(\mathrm{CH}_{3}\right)_{2}\right)-\mathrm{NO}$ & $27 \cdot 1(-6 \cdot 0)$ & $33.9(0 \cdot 8)$ & $31 \cdot 7(-1 \cdot 3)$ & $33 \cdot 1$ \\
\hline 13 & $\mathrm{C}_{6} \mathrm{H}_{5} \mathrm{~N}\left(\mathrm{COCH}_{3}\right)-\mathrm{NO}$ & $29 \cdot 4(-1 \cdot 1)$ & $34 \cdot 5(4 \cdot 0)$ & $31 \cdot 8(1 \cdot 3)$ & $30 \cdot 5$ \\
\hline 14 & $4-\mathrm{NO}_{2}-\mathrm{C}_{6} \mathrm{H}_{4} \mathrm{~N}\left(\mathrm{COCH}_{3}\right)-\mathbf{N O}$ & $31 \cdot 2(-8 \cdot 0)$ & $36 \cdot 4(-2 \cdot 8)$ & $27 \cdot 3(-11.9)$ & $39 \cdot 2$ \\
\hline & $4-\mathrm{Cl}-\mathrm{C}_{6} \mathrm{H}_{4} \mathrm{~N}\left(\mathrm{COCH}_{3}\right)-\mathbf{N O}$ & $29 \cdot 6(0 \cdot 4)$ & $34 \cdot 0(4 \cdot 8)$ & $31 \cdot 3(2 \cdot 1)$ & $29 \cdot 2$ \\
\hline \multicolumn{2}{|c|}{ Mean absolute deviation } & 4.71 & 5.90 & 5.04 & \\
\hline
\end{tabular}
difference of $5.04 \mathrm{kcal} / \mathrm{mol}$, which is outside our desired target accuracy for chemical predictions. In

Table 1. Computed BDEs ( $\mathrm{kcal} / \mathrm{mol})$ in $\mathrm{MeCN}$ for removal of an $\mathrm{NO}$ group in studied molecules by using various density functional methods with $6-31 \mathrm{G}^{* *}$ basis set (ZPVE and BSSE are included).

${ }^{a}$ The value in the parenthesis is the deviation from computed BDE for experimental one.

${ }^{\mathrm{b}}$ The boldface emphasizes the dissociated group. ${ }^{\mathrm{c}}$ The data are from refs $23,24$. 
Table 2. Computed BDEs ( $\mathrm{kcal} / \mathrm{mol})$ in vacuum for removal of an NO group in studied molecules by using various density functional methods with $6-31 \mathrm{G}^{* *}$ basis set (ZPVE and BSSE are included).

\begin{tabular}{|c|c|c|c|c|}
\hline & & B3LYP & B3P86 & B3PW91 \\
\hline Entry & Compound $^{\mathrm{a}}$ & $\mathrm{BDE}$ & $\mathrm{BDE}$ & $\mathrm{BDE}$ \\
\hline 1 & $4-\mathrm{CH}_{3}-\mathrm{C}_{6} \mathrm{H}_{4} \mathrm{~N}\left(\mathrm{C}_{6} \mathrm{H}_{5}\right)-\mathbf{N O}$ & $30 \cdot 2$ & $35 \cdot 3$ & $32 \cdot 5$ \\
\hline 2 & $\mathrm{C}_{6} \mathrm{H}_{5} \mathrm{~N}\left(\mathrm{C}_{6} \mathrm{H}_{5}\right)-\mathbf{N O}$ & $30 \cdot 7$ & $35 \cdot 9$ & $33 \cdot 1$ \\
\hline 3 & $3-\mathrm{Cl}-\mathrm{C}_{6} \mathrm{H}_{4} \mathrm{~N}\left(\mathrm{C}_{6} \mathrm{H}_{5}\right)-\mathbf{N O}$ & $21 \cdot 7$ & $27 \cdot 2$ & $22 \cdot 6$ \\
\hline 4 & $3-\mathrm{NO}_{2}-\mathrm{C}_{6} \mathrm{H}_{4} \mathrm{SO}_{2} \mathrm{~N}\left(\mathrm{CH}_{3}\right)-\mathbf{N O}$ & $36 \cdot 5$ & $42 \cdot 3$ & $38 \cdot 8$ \\
\hline 5 & $4-\mathrm{CH}_{3}-\mathrm{C}_{6} \mathrm{H}_{4} \mathrm{SO}_{2} \mathrm{~N}\left(\mathrm{CH}_{3}\right)-\mathbf{N O}$ & $38 \cdot 4$ & $43 \cdot 7$ & $40 \cdot 6$ \\
\hline 6 & $\mathrm{C}_{6} \mathrm{H}_{5} \mathrm{SO}_{2} \mathrm{~N}\left(\mathrm{CH}_{3}\right)-\mathbf{N O}$ & $38 \cdot 3$ & $43 \cdot 7$ & $40 \cdot 6$ \\
\hline 7 & $4-\mathrm{Cl}-\mathrm{C}_{6} \mathrm{H}_{4} \mathrm{SO}_{2} \mathrm{~N}\left(\mathrm{CH}_{3}\right)-\mathbf{N O}$ & $37 \cdot 9$ & $43 \cdot 2$ & $36 \cdot 2$ \\
\hline 8 & 4- $\mathrm{CH}_{3} \mathrm{O}-\mathrm{C}_{6} \mathrm{H}_{4} \mathrm{SO}_{2} \mathrm{~N}\left(\mathrm{CH}_{3}\right)-\mathbf{N O}$ & $34 \cdot 6$ & $40 \cdot 3$ & $40 \cdot 9$ \\
\hline 9 & $4-\mathrm{CH}_{3} \mathrm{O}-\mathrm{C}_{6} \mathrm{H}_{4} \mathrm{~N}\left(\mathrm{CON}\left(\mathrm{CH}_{3}\right)_{2}\right)-\mathbf{N O}$ & $22 \cdot 6$ & $27 \cdot 3$ & $24 \cdot 6$ \\
\hline 10 & $4-\mathrm{Cl}-\mathrm{C}_{6} \mathrm{H}_{4} \mathrm{~N}\left(\mathrm{CON}\left(\mathrm{CH}_{3}\right)_{2}\right)-\mathbf{N O}$ & $21 \cdot 6$ & $26 \cdot 6$ & $23 \cdot 8$ \\
\hline 11 & $\mathrm{C}_{6} \mathrm{H}_{5} \mathrm{~N}\left(\mathrm{CON}\left(\mathrm{CH}_{3}\right)_{2}\right)-\mathrm{NO}$ & $22 \cdot 7$ & $27 \cdot 6$ & $24 \cdot 9$ \\
\hline 12 & $4-\mathrm{NO}_{2}-\mathrm{C}_{6} \mathrm{H}_{4} \mathrm{~N}\left(\mathrm{CON}\left(\mathrm{CH}_{3}\right)_{2}\right)-\mathbf{N O}$ & $25 \cdot 5$ & $30 \cdot 8$ & $30 \cdot 5$ \\
\hline 13 & $\mathrm{C}_{6} \mathrm{H}_{5} \mathrm{~N}\left(\mathrm{COCH}_{3}\right)-\mathbf{N O}$ & $29 \cdot 0$ & $34 \cdot 0$ & $31 \cdot 2$ \\
\hline 14 & $4-\mathrm{NO}_{2}-\mathrm{C}_{6} \mathrm{H}_{4} \mathrm{~N}\left(\mathrm{COCH}_{3}\right)-\mathbf{N O}$ & $30 \cdot 8$ & $35 \cdot 8$ & $26 \cdot 8$ \\
\hline 15 & $4-\mathrm{Cl}-\mathrm{C}_{6} \mathrm{H}_{4} \mathrm{~N}\left(\mathrm{COCH}_{3}\right)-\mathbf{N O}$ & $28 \cdot 5$ & $33 \cdot 6$ & $30 \cdot 9$ \\
\hline
\end{tabular}

${ }^{\mathrm{a}}$ The boldface emphasizes the dissociated group

table 1, the highest error is found for $\mathrm{C}_{6} \mathrm{H}_{5} \mathrm{~N}\left(\mathrm{C}_{6} \mathrm{H}_{5}\right)$ NO $(12.0 \mathrm{kcal} / \mathrm{mol})$.

The mean absolute deviation between B3P86 results and experiments is $5.90 \mathrm{kcal} / \mathrm{mol}$, which is higher than those found for B3PW91 method. The maximum difference for $\mathrm{B} 3 \mathrm{P} 86$ method is $12.9 \mathrm{kcal} / \mathrm{mol}$ for the BDEs of $\mathrm{C}_{6} \mathrm{H}_{5} \mathrm{~N}\left(\mathrm{C}_{6} \mathrm{H}_{5}\right)-\mathrm{NO}$. Since it is inaccurate to predict the bond dissociation energies, B3P86 method is not recommended to calculate the BDEs of the N-NO bond.

In table 1, we can also see that the values obtained by B3LYP method are closer to the experimental values than those obtained by B3P86 and B3PW91 methods. And the mean absolute deviation between $\mathrm{B} 3 \mathrm{LYP} / 6-31 \mathrm{G}^{* *}$ results and experiments is about $4.71 \mathrm{kcal} / \mathrm{mol}$. In the case of $4-\mathrm{Cl}-\mathrm{C}_{6} \mathrm{H}_{4} \mathrm{~N}\left(\mathrm{COCH}_{3}\right)$ NO, B3LYP method in the $6-31 \mathrm{G}^{* *}$ basis set yields the most accurate $\mathrm{N}-\mathrm{NO}$ bond dissociation energies of $29.6 \mathrm{kcal} / \mathrm{mol}$, only $0.4 \mathrm{kcal} / \mathrm{mol}$ deviation from the experimental value. It is noted that the mean absolute deviation increases from $4.71 \mathrm{kcal} / \mathrm{mol}$ to $5.90 \mathrm{kcal} / \mathrm{mol}$ when B3LYP method is replaced by B3P86 method, which proves that the bond dissociation energy of the N-NO bond is sensitive to the computational methods. Comparing the three DFT methods, it is noted that B3LYP method is the best procedure to compute dissociation energies for the $\mathrm{N}-\mathrm{NO}$ bond among the selected methods.

\section{$3.2 N-N O$ BDEs in vacuum}

The N-NO BDEs in vacuum calculated by using various theoretical methods are summarized in table 2. In comparison, the BDEs calculated by B3P86 functional is consistently higher than those calculated by B3PW91 functional and the difference is about $3.4 \mathrm{kcal} / \mathrm{mol}$. B3LYP functional consistently predicts lower N-NO BDEs than B3PW91 functional by about $0 \cdot 9-6 \cdot 3 \mathrm{kcal} / \mathrm{mol}$.

\subsection{Solvent effects on the BDEs of the N-NO bond}

The solvent effect is defined as solvent effect $=\Delta G$ (homolysis in solvent) $-\Delta G$ (homolysis in a vacuum). Table 3 shows that all BDEs in acetonitrile appear different from their BDEs in a vacuum for the 15 compounds containing the N-NO bond. The most striking feature from the results (table 3 ) is that the BDEs of the N-NO homolysis in acetonitrile are always bigger than those in vacuum except $4-\mathrm{CH}_{3}-$ $\mathrm{C}_{6} \mathrm{H}_{4} \mathrm{~N}\left(\mathrm{C}_{6} \mathrm{H}_{5}\right)-\mathrm{NO}$. The $\mathrm{N}-\mathrm{NO}$ BDEs in vacuum computed by B3P86/6-31G** method are the closest to the computed values in acetontrile and the average solvent effect is $0.78 \mathrm{kcal} / \mathrm{mol}$. The largest average solvent effect is $1.33 \mathrm{kcal} / \mathrm{mol}$ by using B3PW91 method. 
Table 3. Solvent effects of acetonitrile on the BDEs of the N-NO homolysis $(\mathrm{kcal} / \mathrm{mol})$.

\begin{tabular}{|c|c|c|c|c|}
\hline Entry & Compound & B3LYP & B3P86 & B3PW91 \\
\hline 1 & $4-\mathrm{CH}_{3}-\mathrm{C}_{6} \mathrm{H}_{4} \mathrm{~N}\left(\mathrm{C}_{6} \mathrm{H}_{5}\right)-\mathbf{N O}$ & $-2 \cdot 1$ & $-2 \cdot 3$ & $-2 \cdot 5$ \\
\hline 2 & $\mathrm{C}_{6} \mathrm{H}_{5} \mathrm{~N}\left(\mathrm{C}_{6} \mathrm{H}_{5}\right)-\mathrm{NO}$ & $1 \cdot 4$ & $-0 \cdot 4$ & $1 \cdot 5$ \\
\hline 3 & $3-\mathrm{Cl}-\mathrm{C}_{6} \mathrm{H}_{4} \mathrm{~N}\left(\mathrm{C}_{6} \mathrm{H}_{5}\right)-\mathrm{NO}$ & $1 \cdot 3$ & $1 \cdot 0$ & 1.4 \\
\hline 4 & $3-\mathrm{NO}_{2}-\mathrm{C}_{6} \mathrm{H}_{4} \mathrm{SO}_{2} \mathrm{~N}\left(\mathrm{CH}_{3}\right)-\mathbf{N O}$ & $1 \cdot 3$ & $0 \cdot 8$ & $1 \cdot 1$ \\
\hline 5 & $4-\mathrm{CH}_{3}-\mathrm{C}_{6} \mathrm{H}_{4} \mathrm{SO}_{2} \mathrm{~N}\left(\mathrm{CH}_{3}\right)-\mathrm{NO}$ & $0 \cdot 5$ & $-1 \cdot 2$ & $0 \cdot 3$ \\
\hline 6 & $\mathrm{C}_{6} \mathrm{H}_{5} \mathrm{SO}_{2} \mathrm{~N}\left(\mathrm{CH}_{3}\right)-\mathrm{NO}$ & $0 \cdot 5$ & $0 \cdot 3$ & $4 \cdot 3$ \\
\hline 7 & $4-\mathrm{Cl}-\mathrm{C}_{6} \mathrm{H}_{4} \mathrm{SO}_{2} \mathrm{~N}\left(\mathrm{CH}_{3}\right)-\mathrm{NO}$ & $0 \cdot 5$ & $0 \cdot 8$ & $0 \cdot 2$ \\
\hline 8 & $4-\mathrm{CH}_{3} \mathrm{O}-\mathrm{C}_{6} \mathrm{H}_{4} \mathrm{SO}_{2} \mathrm{~N}\left(\mathrm{CH}_{3}\right)-\mathrm{NO}$ & $4 \cdot 3$ & $2 \cdot 3$ & $0 \cdot 2$ \\
\hline 9 & $4-\mathrm{CH}_{3} \mathrm{O}-\mathrm{C}_{6} \mathrm{H}_{4} \mathrm{~N}\left(\mathrm{CON}\left(\mathrm{CH}_{3}\right)_{2}\right)-\mathbf{N O}$ & $1 \cdot 1$ & $1 \cdot 1$ & $2 \cdot 9$ \\
\hline 10 & $4-\mathrm{Cl}-\mathrm{C}_{6} \mathrm{H}_{4} \mathrm{~N}\left(\mathrm{CON}\left(\mathrm{CH}_{3}\right)_{2}\right)-\mathrm{NO}$ & $3 \cdot 1$ & $3 \cdot 1$ & $6 \cdot 1$ \\
\hline 11 & $\mathrm{C}_{6} \mathrm{H}_{5} \mathrm{~N}\left(\mathrm{CON}\left(\mathrm{CH}_{3}\right)_{2}\right)-\mathrm{NO}$ & $1 \cdot 6$ & $1 \cdot 6$ & $1 \cdot 5$ \\
\hline 12 & $4-\mathrm{NO}_{2}-\mathrm{C}_{6} \mathrm{H}_{4} \mathrm{~N}\left(\mathrm{CON}\left(\mathrm{CH}_{3}\right)_{2}\right)-\mathrm{NO}$ & $1 \cdot 6$ & $3 \cdot 1$ & $1 \cdot 2$ \\
\hline 13 & $\mathrm{C}_{6} \mathrm{H}_{5} \mathrm{~N}\left(\mathrm{COCH}_{3}\right)-\mathrm{NO}$ & $0 \cdot 4$ & $0 \cdot 5$ & $0 \cdot 6$ \\
\hline 14 & $4-\mathrm{NO}_{2}-\mathrm{C}_{6} \mathrm{H}_{4} \mathrm{~N}\left(\mathrm{COCH}_{3}\right)-\mathbf{N O}$ & $0 \cdot 4$ & $0 \cdot 6$ & $0 \cdot 5$ \\
\hline \multirow[t]{2}{*}{15} & $4-\mathrm{Cl}-\mathrm{C}_{6} \mathrm{H}_{4} \mathrm{~N}\left(\mathrm{COCH}_{3}\right)-\mathbf{N O}$ & $0 \cdot 5$ & $0 \cdot 4$ & $0 \cdot 4$ \\
\hline & Mean absolute deviation & $1 \cdot 13$ & 0.78 & 1.33 \\
\hline
\end{tabular}

It is noted from table 3 that the solvent effects on the free energy change of the N-NO bond are nearly within $6 \cdot 1 \mathrm{kcal} / \mathrm{mol}$, which is smaller than $1 / 100$ of the free energy change of $\mathrm{N}-\mathrm{NO}$ homolysis in a vacuum. The maximum influence of the solvent in the computed N-NO BDEs is found for 4-Cl$\mathrm{C}_{6} \mathrm{H}_{4} \mathrm{~N}\left(\mathrm{CON}\left(\mathrm{CH}_{3}\right)_{2}\right)-\mathrm{NO}$, for which the consideration of acetonitrile as the solvent increases the N-NO BDE by $6.1 \mathrm{kcal} / \mathrm{mol}$ for B3PW91 method. This may be caused by the presence of electronwithdrawing group $\mathrm{Cl}$, which has different effect on the BDEs of the N-NO bond in different media. In this paper, we should notice that the solvent effect would be more difficult to justify when the solvent is protic solvents such as $\mathrm{H}_{2} \mathrm{O}$, alcohol, etc. because the molecules of protic solvents can form hydrogen bonds on the terminal oxygen of the compounds studied.

\subsection{Substituent effects on the BDE of the $N-N O$ bond}

From the above analysis, we know that B3LYP method at $6-31 \mathrm{G}^{* *}$ basis set is the best procedure to compute the dissociation energies of the $\mathrm{N}-\mathrm{NO}$ bond in acetonitrile. Using B3LYP/6-31G** method, we have studied a series of substituted $N$-nitroso compounds, where substituted group includes both the electron donating and withdrawing groups such as $\mathrm{Cl}, \mathrm{NO}_{2}, \mathrm{CH}_{3}, \mathrm{CH}_{3} \mathrm{O}$. The calculated bond dissociation energies for a set of substituted $\mathrm{N}$-nitroso compounds are listed in table 4 . The results show that the effect of substitution on the BDEs of $N$-nitroso compounds is significant.

Interesting point observed in the selected molecules is the change of BDEs and $\triangle \mathrm{BDE}$ (the difference between the parent and substituted compounds) with the $\sigma_{p}$ values (Hammett constant) of the para substituent on the benzene. The $\sigma_{p}$ values $^{24}$ of $\mathrm{OCH}_{3}, \mathrm{H}, \mathrm{Cl}, \mathrm{NO}_{2}$ groups are $-0 \cdot 27,0 \cdot 0,0.23$ and $0 \cdot 78$, respectively. It is noted that BDEs and $\triangle \mathrm{BDE}$ increase with the augment of $\sigma_{p}$ value for $\mathrm{X}$ $\mathrm{C}_{6} \mathrm{H}_{4} \mathrm{~N}\left(\mathrm{CON}\left(\mathrm{CH}_{3}\right)_{2}\right)-\mathrm{NO}$ and $\mathrm{X}-\mathrm{C}_{6} \mathrm{H}_{4} \mathrm{~N}\left(\mathrm{COCH}_{3}\right)-$ NO. That is to say that the electron donating group such as $4-\mathrm{CH}_{3} \mathrm{O}$ decreases the BDE of the parent X$\mathrm{C}_{6} \mathrm{H}_{4} \mathrm{~N}\left(\mathrm{CON}\left(\mathrm{CH}_{3}\right)_{2}\right)-\mathrm{NO}$, while electron withdrawing group such as 4- $\mathrm{NO}_{2}, 4-\mathrm{Cl}$ increases the BDE of the parent $\mathrm{X}-\mathrm{C}_{6} \mathrm{H}_{4} \mathrm{~N}\left(\mathrm{CON}\left(\mathrm{CH}_{3}\right)_{2}\right)-\mathrm{NO}$ or $\mathrm{X}_{-} \mathrm{C}_{6} \mathrm{H}_{4} \mathrm{~N}$ $\left(\mathrm{COCH}_{3}\right)-\mathrm{NO}$, because these groups always destabilize a radical. However, it is interesting to note that substituent $\mathrm{Cl}$ decreases the N-NO BDE by $0.4 \mathrm{kcal} / \mathrm{mol}$ for $\mathrm{X}-\mathrm{C}_{6} \mathrm{H}_{4} \mathrm{SO}_{2} \mathrm{~N}\left(\mathrm{CH}_{3}\right)-\mathrm{NO}$ and $9.1 \mathrm{kcal} /$ mol for $\mathrm{X}-\mathrm{C}_{6} \mathrm{H}_{4} \mathrm{~N}\left(\mathrm{C}_{6} \mathrm{H}_{5}\right)-\mathrm{NO}$, despite that it is a well-known electron withdrawing substituent.

Generally, it is believed that electron donating group stabilizes the radical (known as radical effect, $\mathrm{RE}$ ) and as a result BDEs decrease; whereas electron 
Table 4. Substituent effects on the BDEs of the N-NO homolysis $(\mathrm{kcal} / \mathrm{mol})$ by using $\mathrm{B} 3 \mathrm{LYP} / 6-31 \mathrm{G}^{* *}$ method for the compounds containing the $\mathrm{N}-\mathrm{NO}$ bond in acetonitrile.

\begin{tabular}{lccccc}
\hline & \multicolumn{2}{c}{$\mathrm{X}-\mathrm{C}_{6} \mathrm{H}_{4} \mathrm{~N}\left(\mathrm{C}_{6} \mathrm{H}_{5}\right)-\mathrm{NO}$} & \multicolumn{3}{c}{$\mathrm{X}-\mathrm{C}_{6} \mathrm{H}_{4} \mathrm{~N}\left(\mathrm{COCH}_{3}\right)-\mathrm{NO}$} \\
\hline $\mathrm{X}$ & $\mathrm{BDE}$ & $\Delta \mathrm{BDE}$ & $\mathrm{X}$ & $\mathrm{BDE}$ & $\Delta \mathrm{BDE}$ \\
\hline $\mathrm{H}$ & $32 \cdot 1$ & $0 \cdot 0$ & $\mathrm{H}$ & $29 \cdot 4$ & $0 \cdot 0$ \\
$4-\mathrm{CH}_{3}$ & $28 \cdot 1$ & $-4 \cdot 0$ & $4-\mathrm{NO}_{2}$ & $31 \cdot 2$ & $1 \cdot 8$ \\
$3-\mathrm{Cl}$ & $23 \cdot 0$ & $-9 \cdot 1$ & $4-\mathrm{Cl}$ & $29 \cdot 6$ & $0 \cdot 2$ \\
& $\mathrm{X}-\mathrm{C}_{6} \mathrm{H}_{4} \mathrm{~N}\left(\mathrm{CON}\left(\mathrm{CH}_{3}\right)_{2}\right)-\mathrm{NO}$ & & $\mathrm{X}-\mathrm{C}_{6} \mathrm{H}_{4} \mathrm{SO}_{2} \mathrm{~N}_{\left(\mathrm{CH}_{3}\right)-\mathrm{NO}}$ \\
& $\mathrm{BDE}$ & $\Delta \mathrm{BDE}$ & $\mathrm{X}$ & $\mathrm{BDE}$ & $\Delta \mathrm{BDE}$ \\
$\mathrm{X}$ & $24 \cdot 3$ & $0 \cdot 0$ & $\mathrm{H}$ & $38 \cdot 8$ & $0 \cdot 0$ \\
$\mathrm{H}$ & $23 \cdot 7$ & -0.6 & $3-\mathrm{NO}_{2}$ & $37 \cdot 8$ & $-1 \cdot 0$ \\
$4-\mathrm{CH}_{3} \mathrm{O}$ & $24 \cdot 7$ & $0 \cdot 4$ & $4-\mathrm{CH}_{3}$ & $38 \cdot 9$ & $0 \cdot 1$ \\
$4-\mathrm{Cl}^{-\mathrm{NO}_{2}}$ & $27 \cdot 1$ & $2 \cdot 8$ & $4-\mathrm{Cl}_{3}$ & $38 \cdot 4$ & $-0 \cdot 4$ \\
& & & $4-\mathrm{CH}_{3} \mathrm{O}$ & $38 \cdot 9$ & $0 \cdot 1$ \\
\hline
\end{tabular}

withdrawing group stabilizes the group state of the molecule (known as ground-state effect, GE) more due to dipolar interaction and thus increase the BDE from the parent molecule.

\section{Conclusion}

In this paper, the bond dissociation energies of the $\mathrm{N}-\mathrm{NO}$ bond for 15 compounds have been calculated by three hybrid DFT B3LYP, B3PW91, B3P86 methods. The basis set superposition error (BSSE) and zero-point vibrational energy (ZPVE) are considered. By comparing all the computed results with the experimental ones, we conclude that B3LYP method with $6-31 \mathrm{G}^{* *}$ basis set can yield reliable BDEs of the $\mathrm{N}-\mathrm{NO}$ bond, which has the average absolute error of $4.71 \mathrm{kcal} / \mathrm{mol}$ and the maximum error of $9.5 \mathrm{kcal} / \mathrm{mol}$. The solvent and substituent effects on the BDEs of the N-NO bond for the compounds studied are also analysed. To account for these effects, the polarizable continuum model is taken into account. It is found that the BDEs of the $\mathrm{N}-\mathrm{NO}$ homolysis in acetonitrile are always bigger than those in a vacuum. In addition, we find that electron donating group stabilizes the radical and as a result BDE decreases; whereas electron withdrawing group stabilizes the ground state of the molecule more due to dipolar interaction and thus increases the BDE. We believe that such NO-related bond information should be useful in understanding the biological functions of nitro oxide, especially its reactions with amino acids in vivo.

\section{Acknowledgements}

We thank the National Natural Science Foundation of China (Grant 10774039) and the Development Program in Science and Technology of Henan Province (No. 102300410114), Henan University of Science and Technology for Young Scholars (No. 2009QN0032) for their support to carry out this work.

\section{References}

1. (a) Bulter A R and Williams D LH 1993 Chem. Soc. Rev. 22 233; (b) Richter-Addo G B and Legzdins P 2002 J. Chem. Rev. 102857

2. (a) Williams D L H 1976 J. Chem. Soc., Perkin Trans. 215 1838; (b) Johal S S and Williams D L H 1980 J. Chem. Soc., Perkin Trans. 2 165; (c) Shirlene M N Y F Oh and Williams D L H J 1989 Chem. Soc., Perkin Trans. 2755

3. Schulz U and McCalla D R 1969 Can. J. Chem. 47 2021

4. Garcia J, González J, Segura R, Urpı'F and Vilarrasa J 1984 J. Org. Chem. 493322

5. (a) Cheng J-P, Zhao Y and Huan Z 1995 Science in China (Series B) 38 1417; (b) Cheng J-P, Lu Y, Liu B, Zhao Y, Sun Y, Wang D and Mi J 1998 Science in China (Series B) 41 215; (c) Cheng J-P, Zhao Y and Huan Z 1993 Tetrahedron 49 5267; (d) Cheng J-P and Zheng Z 1996 Tetrahedron Lett. 371457

6. Hou Y-C, Janczuk A and Wang P G 1999 Curr. Pharmaceut. Des. 5417

7. Bach R D, Ayala P Y and Schlegel H B $1996 \mathrm{~J}$. Am. Chem. Soc. 11812758

8. Glukhovtsev M N and Bach R D 1998 Chem. Phys. Lett. 28651 
9. Abboud J-L M, Castaño O, Davalos J Z and Gomperts R 2001 Chem. Phys. Lett. 337327

10. Li Z-H and Wong M W 2001 Chem. Phys. Lett. 337 209

11. Espinosa-Garcia J 2000 Chem. Phys. Lett. 316 563

12. Zhao Y and Truhlar D G 2005 J. Phys. Chem. A 109 5656

13. Tang Z-X, Li X-H and Zhang X-Z 2009 J. Mol. Struct. (Theochem.) 907126

14. Li X H, Zhang R Z and Yang X D $2007 \mathrm{~J}$. Mol. Struct. (Theochem.) 81743

15. Li X H, Zhang R Z, Cheng X L and Yang X D 2007 J. Mol. Struct. (Theochem.) 82147

16. Frisch M J, Trucks G W, Schlegel H B, Scuseria G E, Robb M A, Cheeseman J R, Zakrzewski V G, Montgomery J A, Stratmann R E, Burant J C, Dapprich S, Millam J M, Daniels A D, Kudin K N, Strain M C, Farkas O, Tomasi J, Barone V, Cossi M, Cammi R, Mennucci B, Pomelli C, Adamo C, Clifford S, Ochterski J, Petersson G A, Ayala P Y, Cui Q, Morokuma K, Malick D K, Rabuck A D, Raghavachari K, Foresman J B, Cioslowski J, Ortiz J V, Baboul A G, Stefanov B B, Liu G, Liashenko A, Piskorz P, Komaromi I, Gomperts R, Martin R L, Fox D J, Keith T, Al- Laham M A, Peng C Y, Nanayakkara A,
Gonzalez C, Challacombe M, Gill P M W, Johnson B, Chen W, Wong M W, Andres J L, Gonzalez C, Head Gordon M, Replogle E S and Pople J A 2003 GAUSSIAN 03, Revision B02, Gaussian Inc.: Pittsburgh PA

17. Becke A D 1993 J. Chem. Phys. 985648

18. Lee C, Yang W and Parr R G 1988 Phys. Rev. B37 785

19. Miehlich B, Savin A, Stoll H and Preuss H 1989 Chem. Phys. Lett. 157200

20. Perdew J P and Wang Y 1992 Phys. Rev. B45 13244

21. Perdew J P 1986 Phys. Rev. B33 8822

22. (a) Cossi M, Barone V, Cammi R and Tomasi J 1996 J. Chem. Phys. Lett. 255 327; (b) Barone, V, Cossi M and Tomasi J 1997 J. Chem. Phys. 107 3210; (c) Mennucci, B and Tomasi J 1997 J. Chem. Phys. 106 5151

23. Xiao-Qing Zhu, Wei-Fang Hao, Hui Tang, Chun-Hua Wang and Jin-Pei Cheng $2005 \mathrm{~J}$. Am. Chem. Soc. 127 2696

24. Luo Y R 2003 Handbook of Bond Dissociation Energies in Organic Compounds (Boca Raton: CRC Press)

25. Cao C Z 2003 Substituent Effects in Organic Chemistry (Beijing: Science Press) 